\title{
Hubungan Komunikasi Terapeutik Perawat Terhadap Tingkat Stres Pasien di Ruang Neurologi Rumah Sakit Umum Daerah dr M.Haulussy Ambon
}

\author{
MarIen Febiyana Patty, Dewi Kartika Sari \& Yafet Pradikatama \\ Fakultas Ilmu Kesehatan Universitas Kristen Satya Wacana
}

\begin{abstract}
Someone who is sick tends to suffer from stress. This type of patient really needs a figure of nurse to reduce their stress level. Beside that's, patient also needs a therapeutic communication. Therefore, a research is done in the Neurology Ward in M Haulussy General Hospital in Ambon with the purpose is to find out the therapeutic communication relationship of the nurses toward the patients' stress level in the Neurology Ward in $M$ Haulussy General Hospital in Ambon. The method used in this study is the correlation quantitative method. The correlation result of the nurses' verbal communication toward the patients' stress level is 0,498 with the significant point of $0,005(p<0,05)$. And the result of the correlation nurses' non verbal communication toward the patients' stress level is 0,497 with the significant point of $0,005(p<0,05)$. While the correlation result of the correlation test between the nurses' therapeutic communication toward the patients' stress level is 0,581 with the significant point of $0,001(p<0,05)$. Therefore, Ho (there is no relation of therapeutic communication to patients stress level) is rejected and $H_{1}$ (There is relation of therapeutic communication to patients stress level) is accepted. It can be concluded that there is a significant relationship between the nurses' therapeutic communication toward the patients' stress level.
\end{abstract}

Key Words : nurses' verbal communication, nurses' non verbal communication, patients'stress level.

\section{PENDAHULUAN}

Semua manusia cenderung akan mengalami stres dalam kehidupannya (Sunaryo,2002:212). Ketika seseorang sakit maka stres akan meningkat. Ketika kita menjadi seorang pasien dan dirawat di rumah sakit kita akan mengalami keadaan stres dan dapat berpengaruh' terhadap .proses penyembuhan. Menurut (Arline,1997:25) orang yang dirawat di rumah sakit beranggapan bahwa rumah sakit adalah tempat yang menimbulkan stres. Dengan demikian sebagian besar pasien yang di rawat di rumah sakit akan membutuhkan kehadiran seorang perawat untuk berkomunikasi dengan mereka. Oleh karena itu sangat dibutuhkan sikap peduli perawat terhadap pasiennya (Arline,1997:25). Keperawatan didasarkan pada suatu hubungan yang merawat dan membantu pasien untuk mencapai proses penyembuhan. Hubungan ini dibangun melalui suatu komunikasi terapeutik yang baik dari perawat kepada pasien (Potter \& Perry,2005:301). 
Menurut Anthony (dalam Mundakir, 2010:38) komunikasi terapeutik sangat penting dan merupakan komunikasi yang direncanakan secara sadar dan dipusatkan serta bertujuan untuk kesembuhan pasien. Data penelitian dari Weimann \& Giles,1988 (dalam Rosalind \& Lucie, 1999:1413) menunjukan bahwa komunikasi perawat sangat penting bagi pasien dengan alasan sebagai proses interaksi dengan pasien, pertukaran informasi serta dukungan selama stres. Menurut Rosalind \& Lucie kurangnya komunikasi yang memuaskan dan berkualitas dari perawat dapat berimplikasi serius terhadap kesehatan fisik dan psikologis pasien.

Seluruh perilaku dan pesan yang disampaikan perawat hendaknya bertujuan terapeutik untuk pasien. Penelitian (Rusmini, 2006:26) di RSU Palangkaraya didapatkan bahwa perilaku perawat khususnya dalam berkomunikasi kurang baik. Penelitian lain yang dilakukan (Prihatiningsih, 2012:40) menunjukan komunikasi terapeutik yang dilakukan di RSUD Kebumen berkriteria cukup dan tingkat stres pasien di ruang Melati RSUD Kebumen mayoritas sedang $(62,7 \%)$. Hal ini dikarenakan perawat belum memahami sepenuhnya akan pentingnya komunikasi terapeutik dengan baik. Kurangnya rasa percaya, empati dan perhatian dari perawat membuat komunikasi perawat tergolong pada kategori cukup. Stres yang dirasakan oleh pasien diakibatkan oleh ketakutan akan adanya komplikasi penyakit, komunikasi perawat, dan juga pembiayaan perawatan di rumah sakit (Prihatiningsih, 2012:40).

Dari pendapat para ahli tersebut fakta yang peneliti temui saat melakukan praktik klinik di RSUD Ambarawa, RS Paru dr Ario Wirawan, RS Ken Saras yakni perawat mampu menjalin hubungan baik dengan pasien, mampu menggunakan komunikasi terapeutik yang baik kepada pasien dan keluarga. Perawat juga menjadi pendengar baik atas keluhan pasien dan kadang mengontrol pasien tanpa dipanggil. Data pra survey peneliti terhadap pasien pada waktu praktik klinik, pasien mengatakan bahwa selama dirawat di rumah sakit pasien sudah mendapatkan pelayanan yang baik dari perawat. Pelayanan tersebut adalah pelayanan dalam tindakan dan cara berkomunikasi.

RSUD M. Haulussy Ambon dipilih menjadi lokasi penelitian ini karena salah satu anggota keluarga peneliti dirawat di ruang Neurologi. Peneliti ingin mengetahui apakah fakta yang peneliti temui di RSUD Ambarawa, RS Paru dr Ario Wirawan, RS Ken Saras sama dengan yang peneliti temui di RSUD M. Haulussy Ambon.

Peneliti berfokus di ruangan neurologi karena ruangan ini merupakan ruangan khusus bagi pasien yang mengalami sakit pada bagian sistem saraf, dimana kondisi pasien di ruangan ini tidak boleh terbeban dengan pikiran. Apabila pasien di ruangan ini terbeban dengan pikiran, entah karena faktor komunikasi terapeutik perawat atau karena faktor lain, maka kecenderungan pasien akan mengalami stres dan hal tersebut berbahaya bagi kondisi pasien tersebut.

\section{METODE PENELITIAN}

Dalam penelitian ini, peneliti menggunakan metode penelitian kuantitatif korelasi atau korelasional yaitu suatu penelitian untuk mengetahui hubungan dan tingkat hubungan antara dua variabel atau lebih tanpa ada upaya untuk mempengaruhi variabel tersebut sehingga tidak terdapat manipulasi variabel (Fraenkel \& Wallen,2008:734). Terdapat dua variabel dalam penelitian ini yaitu komunikasi terapeutik perawat 
sebagai variabel independen dan tingkat stres pasien sebagai variabel dependen.

\section{HIPOTESIS}

$\begin{array}{ll}\text { Ho } & \text { :Tidak ada hubungan komunikasi } \\ \text { terapeutik perawat terhadap } \\ \text { tingkat stres pasien } \\ \text { H1 :Ada hubungan komunikasi } \\ \text { terapeutik perawat terhadap } \\ \text { tingkat stres pasien }\end{array}$

\section{POPULAST}

Populasi penelitian merupakan keseluruhan dari obyek penelitian yang akan diteliti (Nursalam,2001:56). Dalam penelitian ini yang dijadikan populasi yaitu pasien yang dirawat inap di ruang Neurologi Rumah Sakit Umum Daerah dr M Haulussy Ambon yang berjumlah 30 pasien.

\section{SAMPEL}

Sampel adalah bagian dari populasi yang dipilih dengan cara tertentu dan dianggap mewakili seluruh populasi (Nursalam,2001:58). Peneliti menggunakan teknik purposive sampling, yaitu teknik pengambilan sampel secara sengaja. Peneliti menentukan sendiri sampel yang diambil tidak secara acak, tapi ditentukan sendiri oleh peneliti. Kriteria sampel terbagi atas 2 bagian, yaitu :

\section{Kriteria Inklusi}

Kriteria inklusi adalah karakteristik sampel yang layak untuk diteliti (Nursalam,2001:58) kriteria tersebut adalah pasien yang dirawat di ruang Neurologi, pasien dewasa berusia $>17$ tahun, pasien tidak mengalami kecacatan (bisu, tuli, buta), pasien sadar, pasien yang bersedia menjadi responden, dan yang mendapat ijin dari keluarga pasien maupun dari kepala ruangan Neurologi RSUD M Haulussy Ambon

Kriteria Eksklusi

Kriteria eksklusi adalah menghilangkan atau mengeluarkan subjek dari penelitian karena berbagai sebab dengan atau kata lain tidak layak untuk tidak diteliti atau tidak memenuhi kriteria inklusi pada saat penelitian berlangsung (Nursalam,2001:59). Yang termasuk kriteria eksklusi adalah mengalami gangguan orientasi, pasien dewasa berusia $<17$ dan >60 tahun, pasien tidak sadar, pasien yang menolak untuk menjadi responden dan tidak mendapat ijin dari keluarga maupun dari kepala ruangan Neurologi RSUD M Haulussy Ambon.

\section{PENGUMPULAN DATA}

Pada bagian ini peneliti menggunakan instrumen pengumpulan data penelitian kuantitatif berupa kuesioner dan memanfaatkan data yang tersedia dengañ melihat catatan rekam medis pasien di ruang neurologi. Dalam instrumen penelitian, peneliti menghilangkan alternatif jawaban netral (N) dalam penggunaan skala likert karena pengalaman sewaktu melakukan penelitian, responden cenderung memilih jawaban netral $(N)$ sehingga berpengarth pada proses pengolahan hasil penelitian (Azwar,2012:107).

\section{VALIDITAS}

Suatu angket dikatakan valid (sah) jika pertanyaan pada suatu angket mampu mengungkapkan sesuatu yang diukur oleh angket tersebut. Untuk mengetahui validitas intrumen, data hasil uji coba instrumen di analisa dengan uji coba validitas Pearson Product Moment rumus 
yaitu : Teknik statistik yang digunakan adalah korelasi product moment dari Karl Pearson. Sebagai kriteria, pemilihan item berdasarkan korelasi item total dengan konvensi yaitu, batasan koefisien korelasi yang dianggap memuaskan dan memberikan kontribusi yang baik sebesar $\geq 0,30$. Bila jumlah item yang lolos tidak mencukupi atau jauh dari jumlah yang diinginkan maka batas kriteria koefisien korelasi yang semula 0,30 dapat diturunkan menjadi 0,25 (Azwar, 2012:100).

\section{RELIABILITAS}

Reliabilitas merujuk pada konsistensi atau stabilitas sebuah alat ukur (Cozby,2009:26). Secara empirik, tinggi rendahnya reliabilitas ditunjukkan oleh suatu angka yang disebut koefisien reliabilitas yang angkanya berada dalam rentang dari 0 sampai dengan 1,00 (Azwar,2012:101). Untuk melihat apakah reliabel kuisioner baik atau tidak, maka peneliti menggunakan standar reliabel menurut (Azwar,2000:57) sebagai berikut:

$\alpha \leq 0,7 \quad:$ tidak reliabel

$0,7 \leq \alpha \leq 0,8$ : cukup

$0,8 \leq a \leq 0,9$ : baik

$0,9 \leq \alpha \leq 1,0 \quad$ : sangat baik

Semakin tinggi, koefisien reliabilitas mendekati angka 1,00 berarti semakin tingginya reliabilitas. Sebaliknya, koefisien yang semakin rendah mendekati $o$, berarti semakin rendahnya reliabilitas (Azwar, 2010:58). Dengan menghitung koefisien reliabilitas hasil ukur pada suatu subjek penelitian, maka dapat diperkirakan tingkat kepercayaan hasil pengukuran alat tersebut bagi kelompok subjek yang diteliti. Suatu alat ukur dikatakan mempunyai taraf kepercayaan yang tinggi apabila alat ukur tersebut mampu memberikan hasil yang tetap. Dalam penelitian ini, penulis menggunakan teknik uji reliabilitas Alpha Cronbach.

Dalam penelitian ini, hasil akan diukur dengan bantuan program khusus komputer statistik yaitu SPSS seri 16.0 for windows.

\section{Hasil uji validitas dan reliabilitas komunikasi terapeutik perawat}

Variabel komunikasi terapeutik memilki 22 ITEM pertanyaan, setelah di lakukan uji validitas hasil yang diperoleh adalah nilai koefisien pada item $2=0,19$ dan item $7=0,28$ nilai koefisien pada kedua item tersebut $<0,30$ sehingga Item 2 dan item 7 dinyatakan tidak valid, item yang dinyatakan valid adalah item1,3,4,5,6,8,9,10,11,12,13,14,15,16 , $\mathbf{1 7 , 1 8 , 1 9 , 2 0 , 2 1 , 2 2}$ dari hasil tersebut item yang valid akan peneliti gunakan dalam penelitian.

Hasil uji reliabilitas variabel komunikasi terapeutik diperoleh nilai koefisien alpha sebesar $\mathbf{0 , 8 8 9}$. Hal ini berarti instrumen komunikasi terapeutik adalah reliable dengan standar baik.

\section{Hasil uji validitas dan reliabilitas tingkat stres pasien}

Variabel tingkat stres pasien memiliki 13 ITEM pertanyaan setelah di lakukan uji validitas hasil yang diperoleh adalah nilai koefisien pada item $11=0,27<0,30$ sehingga item 11 dinyatakan tidak valid, item yang dinyatakan valid adalah item $1,2,3,4,5,6,7,8,9,10,12,13$. Item yang valid akan peneliti gunakan dalam penelitian.

Hasil uji reliabilitas variabel tingkat stres pasien diperoleh nilai koefisien alpha sebesar $=\mathbf{0 , 8 8 0}$. Hal ini berarti instrumen tingkat stres pasien adalah reliable dengan standar baik. 
Teknik Pengelompokan dan Analisis Data

Pengolahan data

Editing (memeriksa) : Editing adalah memeriksa daftar observasi yang telah dilakukan mencakup kelengkapan pengisian lembar observasi, keterbacaan pengisian dan relavansi pengisian.

Entry Data : Nilai-nilai dalam lembar observasi dijumlahkan dan dimasukan dalam tabel hitung, melalui program microsoft office excel.

Cleaning : Pembersihan data, dengan melihat variabel apakah data sudah benar atau belum.

Analisa data

Metode yang digunakan data melalaui metode kuantitatif yaitu metode dengan analisa yang dapat digunakan untuk menganalisa variabel yang dapat diukur dengan angka untuk memecahkan masalah. Analisa yang digunakan adalah analisa korelasi yang digunakan untuk mengetahui hubungan komunikasi terapeutik perawat terhadap tingkat stres pasien (A.Aziz,2007:107-108).

\section{HASIL PENELITIAN}

\section{PROFIL RESPONDEN}

Responden penelitian seluruhnya berjumlah 30 responden. Gambaran umum responden penelitian berisi tentang karakteristik jenis kelamin, usia, tingkat pendidikan, dan pekerjaan.

Jenis Kelamin

Berdasarkán penelitian dan hasil distribusi frekuensi didapatkan bahwa jumlah responden laki-laki sebanyak 17 responden $(57,7 \%)$ dan jumlah responden perempuan sebanyak 13 responden $(43,3 \%)$.
Usia

Berdasarkan penelitian dan hasil distribusi frekuensi didapatkan bahwa responden yang berusia 20-30 tahun yaitu sebanyak 7 responden ( $23,3 \%)$, berusia 3140 tahun sebanyak 5 responden $(16,7 \%)$, berusia 41-50 tahun sebanyak 6 responden (20,0\%), berusia 51-60 tahun sebanyak 12 responden $(40,0 \%)$.

Berdasarkan diagram frekuensi usia, partisipan yang berusia 51-60 tahun lebih banyak dengan jumlah 12 partisipan (40,0\%). Menurut survey kesehatan rumah tangga (SKRT,1995:22) menyimpulkan bahwa penyakit pada sistem. degeneratif dan sistem saraf banyak ditemukan pada usia 60 tahun ke atas. Karena faktor kemunduran fungsi organ sehingga pada usia tersebut rawan terhadap gangguan kesehatan. Stres yang dialami bahkan menunjukan sikap masa bodoh, kurang ramah dan kurang beradaptasi dengan lingkungan. Sama halnya dengan fakta yang peneliti temukan saat melakukan penelitian di ruang Neurologi. Salah seorang anggota keluarga pasien (Ny. H) mengatakan bahwa (Ny. H) sangat tidak betah berada di rumah sakit dan selalu meminta agar segera pulang. (Ny. H) sering marahmarah ketika ditanya tentang kondisinya, terkadang terjadi perubahan mood yang sebelumnya tenang kemudian berubah menjadi marah.

\section{Tingkat pendidikan}

Berdasarkan penelitian dan hasil distribusi frekuensi didapatkan bahwa tidak ada responden yang tidak sekolah dan tidak ada yang tidak tamat SD, yang berpendidikan SD sebanyak 2 responden $(6,7 \%)$, berpendidikan SMP sebanyak 5 responden $(16,7 \%)$, berpendidikan SMA 15 responden $(50,0 \%)$ dan berpendidikan Akademi/Universitas sebanyak 8 responden $(26,7 \%)$. 
Pekerjaan

Berdasarkan penelitian dan hasil distribusi frekuensi didapatkan bahwa tidak ada responden yang bekerja sebagai wiraswasta, tidak bekerja sebanyak 1 responden $(3,3 \%)$, yang bekerja sebagai ${ }^{*}$ swasta sebanyak 4 responden (13,3\%), PNS/ABRI sebanyak 5 responden $(16,7 \%)$, pensiunan PNS/ Purnawirawan sebanyak 3 responden (10,0\%), dan lain-lain sebanyak 17 responden (56,7\%). Jenis pekerjaan partisipan dalam kategori lainlain adalah petani, ibu rumah tangga, nelayan, penjahit, sopir angkutan umum.

\section{PELAKSANAAN PENELITIAN}

Peneliti melakukan penelitian di Rumah Sakit Umum Daerah Dr M Haulussy Ambon, pelaksanaan penelitian dimulai tanggal 13 -20 oktober 2014. Sebelum melakukan penelitian peneliti bertemu dan menjelaskan kepada kepala ruangan Neurologi terlebih dahulu tentang tujuan peneliti melakukan penelitian di ruangan neurologi RSUD. HAULUSSY M Ambon. Peneliti melaksanakan penelitian ini setelah mendapat ijin dari kepala ruangan neurologi dan di minta langsung membagikan kuisioner kepada pasien di temani oleh seorang perawat jaga.
Responden yang di teliti adalah pasien yang mengalami gangguan pada sistem saraf (stroke dan cedera kepala), untuk itu peneliti mengkondisikan keadaan pasien dalam melaksanakan penelitian. Peneliti sebelumnya mendatangi pasien dan keluarganya untuk memperkenalkan nama dan institusi peneliti sekaligus membina hubungan saling percaya dengan pasien. Peneliti memberikan penjelasan mengenai maksud dan tujuan peneliti melakukan penelitian kepada pasien dan sekaligus meminta ijin partisipasi pasien untuk berperan serta dalam penelitian ini dengan mengisi kuisioner yang disebarkan kepada mereka. Peneliti menemani pasien dalam proses pengisian kuisioner dengan maksud agar selama pengisian kuisioner ada pernyataan yang tidak di mengerti oleh pasien peneliti bisa langsung menjelaskan. Selama pengisian kuisioner ada 5 pasien yang tidak sekaligus menyelesaikan pengisian kuisioner untuk itu peneliti membuat kontrak waktu dengan pasien dalam penyelesaian pengisian kuisioner tersebut. Setelah pengisian kuisioner selesai langsung diberikan kepada peneliti dan peneliti langsung mengecek kuisioner yang telah di isi oleh pasien. Dari kuisioner yang di sebar semuanya terkumpul kembali dan semuanya itu bisa di pakai dalam penelitian ini. 
Marlen Febiyana Patty, Dewi Kartika Sari \& Yafet Pradikatama, Hubungan Komunikasi Terapeutik Perawat Terhadap Tingkat Stres Pasien di Ruang Neurologi Rumah Sakit Umum Daerah dr M. Haulussy Ambon

Tabel 1 : Hasil Uji Korelasi Komunikasi terapeutik perawat dengan tingkat stres pasien di ruang Neurologi RSUD M. Haulussy Ambon

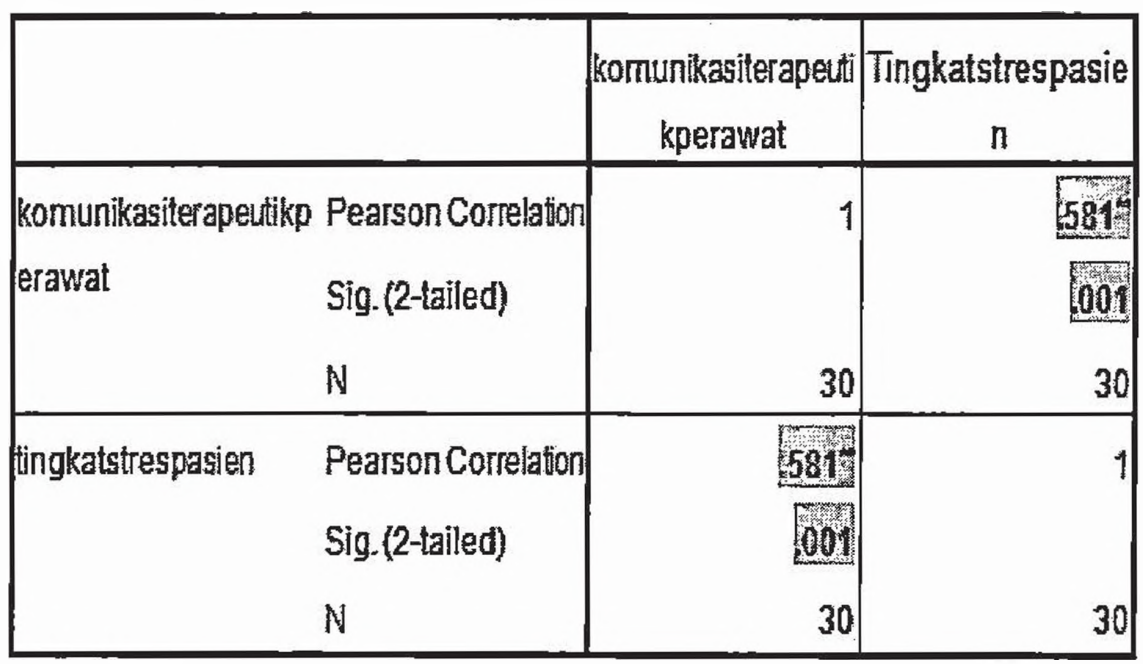

Berdasarkan hasil perhitungan uji korelasi pada tabel I diperoleh koefisien korelasi antara komunikasi terapeutik perawat dengan tingkat stres pasien sebesar 0,581 dengan signifikansi $=0,001$ $(p<0,05)$ yang berarti ada hubungan yang berkriteria sedang dan signifikan antara komunikasi terapeutik perawat dengan tingkat stres pasien maka Ho ditolak dan $\mathrm{H} 1$ diterima. Jadi, dapat disimpulkan bahwa ada hubungan yang signifikan antara komunikasi terapeutik perawat terhadap tingkat stres pasien.

Tabel 2 : Analisa hubungan komunikasi verbal perawat dengan tingkat stres pasien di ruang Neurologi RSUD M. Haulussy Ambon

\begin{tabular}{|c|c|c|c|}
\hline & & $\begin{array}{c}\text { komunikasivetral } \\
\text { Derawa! }\end{array}$ & $\begin{array}{c}\text { Tingkałstrespasi } \\
\text { en }\end{array}$ \\
\hline \multicolumn{2}{|c|}{ Komunikasiverbalpera Pearson Correlation } & 1 & $\begin{array}{l}09980 \\
0005\end{array}$ \\
\hline Wat & $N$ & 30 & 30 \\
\hline \multirow[t]{3}{*}{ Tingkatstrespasien } & Pearson Correlation & $498^{-1}$ & \\
\hline & Sig. (2-tajled) & 005 & \\
\hline & $N$ & 30 & 30 \\
\hline
\end{tabular}

Berdasarkan hasil perhitungan menggunakan pearson product moment diperoleh nilai koefisien korelasi antara komunikasi verbal perawat dengan tingkat stres pasien sebesar 0,498 dengan signifikanksi $=0,005(p<0,05)$ yang artinya terdapat hubungan yang berkriteria sedang dan signifikan antara komunikasi verbal perawat dengan tingkat stres pasien. 
Tabel 3 : Analisa hubungan komunikasi non verbal perawat dengan tingkat stres pasien di ruang Neurologi RSUD M. Haulussy Ambon

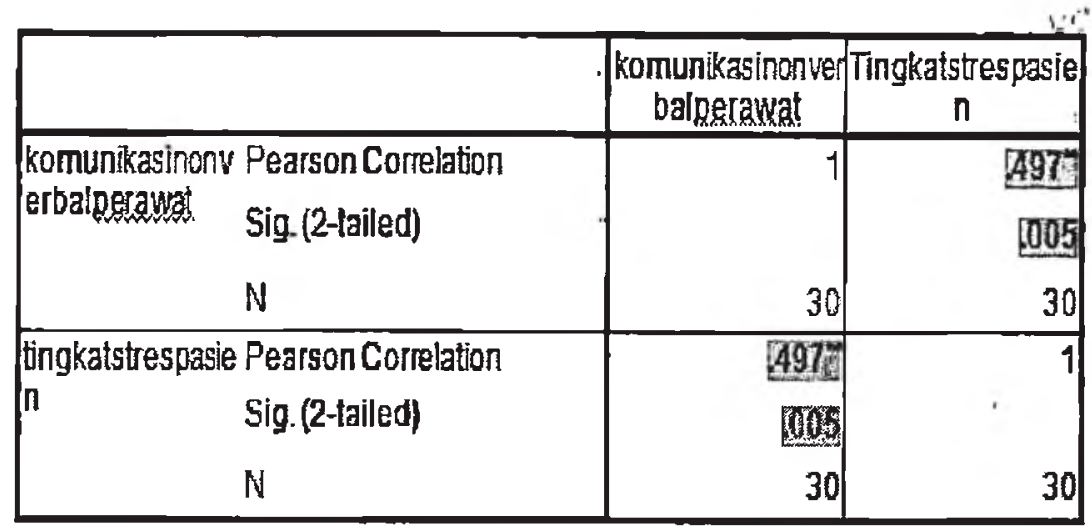

Berdasarkan hasil perhitungan menggunakan pearson product moment diperoleh nilai koefisien korelasi antara komunikasi non verbal dengan tingkat stres pasien sebesar 0,497 dengan signifikansi $=0,005(p$ $<0,05$ ) yang artinya terdapat hubungan yang berkriteria sedang signifikan antara komunikasi nonverbal perawat dengan tingkat stres pasien.

Hasil penelitian nilai korelasi komunikasi verbal dan nonverbal perawat adalah 0,498 dan 0,497 dengan signifikansi 0,005 menggambarkan bahwa bukan hanya komunikasi perawat yang merupakan satu-satunya faktor penyebab stres pasien yang dirawat di ruang Neurologi namun masih ada faktor lain yang mempengaruhi tingkat stres pasien ketika di rawat di rumah sakit. Menurut (Abraham \& Shanley, 1997:150-152) bahwa stres pasien diakibatkan ketika pasien akan menjalani prosedur medis yang terkadang sangat kompleks dan karena penyakit yang dirasakan atau diderita oleh pasien tersebut.

Duff \& Hollingshead (dalam Muhazam,1995:153) mewawancarai sejumlah 161 pasien yang semuanya menyatakan stres dan takut pada saat masuk rumah sakit bahkan 52\% dari pasien tersebut merasa sangat ketakutan. Ketakutan dan stresor yang dialami berkaitan dengán ancaman penyakit yang diderita.

Menurut (Smeet,1994:159) bahwa berbagai macam faktor yang amat penting dalam intervensi untuk meningkatkan kepuasan pasien dan mengurangi tingkat kecemasan, ketakutan dan stres adalah pengontrolan, komunikasi dan dukungan sosial.

\section{PEMBahasaN}

\section{Komunikasi Terapeutik Perawat}

Komunikasi terapeútik bukan tentang apa yang dilakukan oleh seorang perawat, tetapi bagaimana perawat itu melakukan komunikasi 
Marlen Febiyana Patty, Dewi Kartika Sari \& Yafet Pradikatama, Hubungan Komunikasi Terapeutik Perawat Terhadap Tingkat Stres Pasien di Ruang Neurologi Rumah Sakit Umum Daerah dr M.Haulussy Ambon

dengan pasien serta mengembangkan hubungan yang saling membantu antara perawat dengan pasien yang dengan tujuan untuk kesembuhan pasien tersebut. (Suryani,2006:152).

Salah satu hal yang dilakukan perawat dalam menjaga kerjasama yang baik dengan pasien dalam membantu mengatasi masalah pasien adalah dengan berkomunikasi. Dengan berkomunikasi perawat dapat mendengarkan perasaan pasien dan menjelaskan prosedur tindakan keperawatan (Mundakir, 2010:125). Komunikasi perawat dan pasien memegang peranan penting dalam membantu pasien memecahkan masalah yang dihadapi. Diharuskan seorang perawat di ruang Neurologi menerapkan kemampuannya dalam berkomunikasi terapeutik secara efektif ketika melayani pasien, karena tujuan dari komunikasi terapeutik adalah untuk kesembuhan pasien sendiri.

Berdasarkan hasil penelitian di peroleh hasil bahwa dari 30 responden menggambarkan komunikasi yang dilakukan perawat di ruang Neurologi terhadap pasien berkriteria sedang dengan nilai pearson correlation 0,498 dengan signifikansi 0,005 . Menurut pendapat seorang pasien ( $\mathrm{Ny}$. H) bahwa perawat di ruang Neurologi sudah menjalankan tugasnya merawat pasien disini namun ada beberapa perawat ketika berbicara dengan pasien kadang tidak disertai dengan ekspresi yang baik. Menurut pendapat tersebut perawat telah menjalankan proses komunikasi dengan pasien yang di rawat di ruangan neurologi namun perawat sendiri masih kurang menerapkan prinsip dasar dalam komunikasi terapeutik yaitu komunikasi secara verbal maupun nonverbal.

\section{Tingkat Stres}

Tingkat stres menurut (Rasmun, 2004:22) terbagi atas tiga bagian yaitu stres ringan, stres sedang dan stres berat. Sesuai hasil crosstab usia responden dengan tingkat stres didapatkan bahwa kategori usia 51-60 tahun sebanyak 12 responden (40\%) mengalami stres tingkat sedang. Memasuki lanjut usia merupakan stresor bagi seseorang. Hal ini tergantung pada kepribadian, dan lingkungan sosialnya. Usia tua ditandai dengan adanya berbagai stres. Semakin tua seseorang akan mengalami kerusakan biologis, sosial dan kesulitan ekonomi. Menurut Schulz \& Rau, 1988 (dalam Shika \& Smita, 2013) tekanan terbesar dialami oleh usia yang lebih tua berbeda dengan usia muda dan usia tengah. Sebagai contoh orang tua yang dipisahkan dari anak-anak mereka, menghadapi kematian pasangan, kurang adanya dukungan dari kerabat dan teman-teman. Oleh karena sering menghadapi begitu banyak masalah dalam hidup mereka mengakibatkan stres sering terjadi dan mempengaruhi kesehatan mental serta fisik mereka. (Shika \& Smita, 2013:666-667).

Berdasarkan hasil crosstab jenis kelamin bahwa laki-laki sebanyak 17 responden $(56,7 \%)$ mengalami tingkat stres sedang. Beberapa peneliti menyatakan bahwa jenis kelamin merupakan penentu perbedaan 
pengaruh sumber stres terhadap emosi dan kelangsungan fisik seseorang. Beberapa, ahli menemukan bahwa tingkat stres yang dialami wanita hampir tidak ada perbedaan dengan tingkat stres yang dialami oleh pria (Collins, 1993:11). Menurut (Bernstein \& Douglas, 2012:549) stres lebih besar dialami oleh wanita dibandingkan dengan pria meskipun demikian pria akan menampakan gejala-gejala tersebut dalam jangka waktu yang lebih panjang, sehingga pria lebih cenderung sakit berkepanjangan dan memiliki daya tahan tubuh yang lemah dari pada wanita (Daniel \& Jason, 2013:126).

Hasil kategori pekerjaan sebanyak 17 responden (56,7\%) mengalami tingkat stres sedang. Aarass et al (dalam Julian,2001:550) yang menyatakan bahwa stres di bidang pekerjaan mengacu pada semua karakterisktik pekerjaan artinya tidak hanya pada satu jenis pekerjaan. Stres kerja merupakan respon tubuh yang sifatnya non spesifik terhadap setiap tuntutan beban atasnya, yaitu bagaimana respon tubuh seseorang ketika mengalami pekerjaan yang berlebihan. Jika seseorang mampu mengatasinya artinya tidak ada gangguan fungsi organ tubuh. Tetapi sebaliknya jika seseorang tidak mampu mengatasinya maka orang tersebut cenderung mengalami stress sehingga berdampak mengalami gangguan pada satu atau lebih fungsi organ tubuh dan mengakibatkan seseorang tidak lagi dapat menjalankan tugasnya dengan baik.

Ketika kita menjadi seorang pasien dan di rawat di rumah sakit, kita beranggapan bahwa rumah sakit adalah tempat yang menimbulkan stress (Arline, 1997:56). Pasien (Tn.N) yang di rawat di ruang Neurologi yang telah mendapat informasi tentang keadaannya dari dokter maupun perawat kadang ingin membicarakan kembali tentang informasi yang ia dapat, kadang ia akan memilih dengan perawat yang mana hendak ia ajak untuk berbicara. Rasa cemas dan stres banyak di rasakan oleh pasien yang di rawat di ruang neurologi karena faktor komunikasi, kesakitan di anggota tubuh dan merasa terganggu karena keramaian pada waktu berkunjung keluarga di ruangan. Biasanya mereka hanya mendengar apa yang dikatakan oleh perawat setelah itu menilai cara perawat menyampaikan informasi kepada mereka.

\section{Hubungan Komunikasi}

Terapeutik Perawat terhadap Tingkat stres pasien

Dari hasil pengolahan data hasil penelitian diperoleh koefisien hubungan antara komunikasi terapeutik perawat dengan tingkat stres pasien sebesar 0,581 dengan signifikansi $=0,001 \quad(\mathrm{p}<0,05)$ (Sugiyono, 2008:78) yang berarti ada hubungan yang berkriteria sedang dan bersignifikan antara komunikasi terapeutik perawat dengan tingkat stres pasien. Hubungan yang berkriteria sedang mengartikan bahwa tidak sepenuhnya faktor komunikasi perawat yang mempengaruhi tingkat stres pasien namun masih ada faktor lain. Menurut salah seorang pasien (Tn. N) bahwa faktor keramaian di ruangan neurologi dan kesakitan yang 
di rasakan di anggota tubuh juga mempengaruhi tingkat stres pada pasien di ruang neurologi.

Seperti yang dijelaskan oleh (Abraham \& Shanley,1997:150-152) bahwa stres pasien juga diakibatkan ketika pasien akan menjalani prosedur medis yang terkadang sangat kompleks dan karena penyakit yang dirasakan atau diderita oleh pasien tersebut. Dan untuk mengurangi tingkat kecemasan, ketakutan dan stres adalah dengan pengontrolan, komunikasi dan dukungan sosial. Komunikasi dari perawat sangat dibutuhkan oleh pasien dan keluarganya baik itu komunikasi verbal maupun nonverbal. Melalui komunikasi terapeutik secara tepat dapat membantu meringankan beban pasien dan membantu pasien dalam proses penyembuhannya. Bagi pasien, berkomunikasi dapat mengeluarkan keluhan - keluhan yang mereka hadapi sekaligus merupakan suatu bentuk pengobatan (Isyanto \& Syafei, 2003:59-60).

Berdasarkan hasil perhitungan diperoleh nilai koefisien korelasi antara komunikasi verbal perawat yang meliputi kejelasan suara, kekerasan suara, bahasa yang sedarhana, kecepatan suara, umpan balik terhadap tingkat stres pasien sebesar 0,498 dengan signifikansi = 0,005 ( $p<0,05$ ) yang artinya terdapat hubungan yang berkriteria sedang dan signifikan antara komunikasi verbal perawat terhadap tingkat stres pasien. Sedangkan nilai koefisien korelasi antara komunikasi non verbal perawat yang meliputi kontak mata, sentuhan, gerakan tubuh, intonasi, ekspresi wajah, penampilan terhadap tingkat stres pasien sebesar 0,497 dengan signifikansi $=0,005(\mathrm{p}<0,05)$ yang artinya terdapat hubungan yang berkriteria sedang dan signifikan antara komunikasi non verbal perawat dengan tingkat stres pasien. hubungan yang berkriteria sedang dan bersignifikan artinya komunikasi verbal dan non verbal yang diterapkan oleh perawat di ruangan neurologi juga mempengaruhi tingkat stres pasien yang di rawat di ruangan tersebut.

Komunikasi verbal dan nonverbal perawat mempengaruhi tingkat stres pasien yang dirawat di ruang Neurologi, diakibatkan oleh kurangnya keterampilan berkomunikasi yang baik dari perawat terhadap pasien maupun keluarga pasien. Perawat harus waspada akan adanya komunikasi non verbal yang mengikuti pesan verbal yang disampaikan pada pasien. Pesan verbal harus menguatkan atau diikuti oleh isyarat non verbal yang tepat Menurut (Anemona \& Elena, 2014:3115), pesan non verbal penting dan mampu mengidentifikasi keadaan mental seseorang, sehingga cara menginterprestasikan pesan non verbal harus dengan penafsiran yang benar. Komunikasi verbal sebagian besar di pandang sebagai proses interaktif yang penting bagi pasien untuk memberikan informasi dan dalam pemberian dukungan untuk membantu dalam mengurangi stres.

Menurut (Rosalind \& Lucie, 1999:1412) komunikasi verbal juga dapat mengurangi stres yaitu dengan cara perawat memfasilitasi pasien menggunakan mekanisme koping yang 
adaptif. Komunikasi verbal sangat akurat dan lazim dipakai di rumah sakit karena perawat berkomunikasi langsung tatap muka dengan pasien, berkomunikasi tepat waktu dan cepat mendapat respon dari pasien sehingga sangat di perlukan keterampilan baik dari perawat untuk mampu berkomunikasi baik dengan pasien hal ini dikarenakan komunikasi ini bertujuan untuk kesembuhan pasien (Purwanto,2003:137-138).

Menurut studi Lawrence,1995 (dalam Rosalind \& Lucie,1999:14151417) pasien yang di rawat di rumah sakit menggambarkan bagaimana mereka mendengar, mengerti dan menanggapi secara emosional apa yang dikatakan oleh petugas kesehatan. Data hasil penelitian yang peneliti dapatkan bahwa komunikasi yang diterapkan oleh perawat terhadap pasien di ruang Neurologi memiliki nilai korelasi 0,581 dengan signifikansi $0,001 \quad(p<0,05)$ yang artinya mempunyai korelasi sedang. Data hasil penelitian ini menggambarkan juga bahwa ada faktor lain yang belum diketahui yang mempengaruhi tingkat stres pasien selain faktor komunikasi perawat. Faktor lain yang peneliti dapatkan berdasarkan informasi dari pasien yang dirawat di ruang Neurologi adalah selain faktor komunikasi perawat faktor keramaian di ruangan dan rasa sakit yang dirasakan di anggota tubuh.

Data penelitian sebelumnya dari Weimann \& Giles,1988 (dalam Elliot \& Wright,1999:3020-3021) menunjukan bahwa komunikasi dalam keperawatan sangat penting dengan alasan sebagai akses dan pertukaran informasi antara perawat dengan pasien serta dukungan emosional selama stres. Kurangnya komunikasi yang memuaskan dan berkualitas dari perawat dapat berimplikasi serius terhadap kesehatan fisik dan psikologis pasien.

Perawat yang terapeutik berarti melakukan interaksi dengan pasien, interaksi tersebut untuk memfasilitasi proses penyembuhan pasien, sedangkan hubungan terapeutik artinya suatu hubungan interaksi yang mempunyai sifat menyembuhkan dan berbeda dengan hubungan sosial. Hubungan ini di bangur untuk keuntungan pasien. Pasien tidak boleh diremehkan, pasien mempunyai motivasi sembuh yang tinggi akan selalu berfikir dia akan segera sembuh dari penyakitnya, dan keadaan sekitar mampu mempengaruhinya, sebagian besar pasien merindukan perawat untuk berkomunikasi dengan mereka untuk membantu meningkatkan rasa pengendalian diri salah satunya melalui pemberian informasi dan penjelasan yang benar dan tepat, informasi dapat diberikan dengan baik apabila didukung oleh pelaksana komunikasi yang baik dari perawat kepada pasien maupun keluarga pasien (Maramis,2005:106).

\section{KESIMPULAN DAN SARAN}

\section{Kesimpulan}

Dari hasil penelitian dan pembahasan dapat diambil kesimpulan untuk menjawab tujuan dari penelitian sebagai berikut :

- Berdasarkan hasil perhitungan uji korelasi diperoleh koefisien 
korelasi antara komunikasi terapeutik perawat terhadap tingkat stres pasien sebesar 0,581 dengan signifikansi $=$ $0,001(p<0,05)$ yang berarti ada hubungan yang berkriteria sedang dan signifikan antara komunikasi terapeutik perawat terhadap tingkat stres pasien, maka Ho ditolak dan $\mathrm{H} 1$ diterima. Hubungan yang berkriteria sedang mengartikan bahwa tidak sepenuhnya faktor komunikasi perawat yang mempengaruhi tingkat stres pasien namun masih ada faktor lain. Menurut salah seorang pasien (Tn. N) bahwa faktor keramaian di ruangan neurologi dan kesakitan yang di rasakan di anggota tubuh juga mempengaruhi tingkat stres pada pasien di ruang neurologi.

- Berdasarkan hasil perhitungan diperoleh nilai koefisien korelasi antara komunikasi verbal perawat dengan tingkat stres pasien sebesar 0,498 dengan signifikansi $=0,005$ $(p<0,05)$ dan korelasi antara komunikasi non verbal sebesar 0,497 dengan signifikansi $=$ $0,005(p<0,05)$ yang artinya terdapat hubungan yang berkriteria sedang dan signifikan antara komunikasi verbal dan nonverbal perawat dengan tingkat stres pasien.
Hubungan yang berkriteria sedang dan bersignifikan artinya komunikasi verbal dan non verbal yang diterapkan oleh perawat di ruangan Neurologi juga mempengaruhi tingkat stres pasien yang di rawat di ruangan tersebut.

\section{Saran}

- Ilmu Keperawatan

Disarankan hasil penelitian ini menjadi masukan dan pengembangari dalam ilmu keperawatan khususnya dalam bidang komunikasi terapeutik.

- Rumah Sakit

Perlu adanya pelatihan tentang komunikasi terapeutik perawat terhadap pasien. Serta perlu meningkatkan mutu pelayanan kesehatan yang dilakukan, khususnya sikap, kemampuan dan keterampilan perawat dalam melakukan komunikasi terapeutik terhadap pasien.

- Peneliti selanjutnya

Bagi peneliti sekaligus penelitian selanjutnya agar perlu meneliti apakah ada faktor lain selain faktor komunikasi yang mempengaruhi tingkat stres pasien yang di rawat di ruang neurologi RSUD Dr. $M$. Haulussy Ambon. 
Jurnal kornunikasi, Volume 9, Nomor 2, April 2015

\section{DAFTAR PUSTAKA}

Abraham, C., Shanley, F. 1997. Psikologi Sosial Untuk Perawat. Jakarta : EGC Azwar, S. 2000. Reliabilitas dan Validitas. Yogyakarta : Pustaka Belajar

Azwar, S. 2012. Penyusunan skala psikologi. Edisi 2. Yogyakarta : Pustaka Pelajar

Arline, Matthews. 1997. Belajar merawat di bangsal penyakit dalam. Jakarta : ECG

Anemona, Paunescu., Elena, Simona Indreica. 2014. Use of non-verbal communication in preschoolers emotional development. Vol 10

A.Aziz, A.H. 2007. Metode Penelitian Keperawatan dan Teknik Analisis Data. Jakarta : Salemaba Medika

Bernstein, A., Douglas., et all. 2012. Psychology : An International Discipline in Context : Australian \& New Zaeland edition.Wadsworth Cengage Learning

Badan litbang kesehatan. (1995). Laporan SKRT 1995. Badan Litbang Kesehatan. Jakarta

Cozby, P.C. 2009. Methods in behavioral research. Yogyakarta : Pustaka Pelajar

Collins, K.M. 1993. Stress and departures from the public accounting profession : A study of gender difference. Accounting Horizons (March)

Daniel, Freeman., Jason, Freeman. 2013. $\therefore$ The Stressed sex : Uncovering the truth about men, women, and mental "health. Oxford University Press

Fraenkel, J.R., Wellen, N.E. 2008. How to Design and Evaluate research in Education. New York : McGrawHill
Istiyanto, S.B., Syafei, M. 2003. Jurnal : Studi Komparatif Strategi Komunikasi Rumah Sakit Umum Daerah Banyumas dan Rumah Sakit Margono Soekarjo Purwokerto Terhadap Penyembuhan Pasien. file:///C:/Windows/svstem32/config/ systemprofile/Downloads/25775078-1-PB\%20(1).pdf diakses 5 januari 2015

Julian, Barling. 2001. Handbook of work sress. India Pvt. Ltd

Mundakir. $2010 . \quad$ Komunikasi Keperawatan Aplikasi dalam Pelayanan. Yogjakarta : GrahaI Ilmu Muhazam, F. 1995. Memperkenalkan Sosiologi Kesehatan. Jakarta : UI Press

Maramis, W.F. 2005. Ilmu Kedokteran Jiwa. Airlangga Universitas : Surabaya

Nursalam, Pariani. 2001 . Pendekatan Praktis Metodologi Riset Keperawatan. Jakarta : Sagung Seto

Purwanto, Hery. 2003. Komunikasi Untuk Perawat. Jakarta : EGC

Potter, Perry. 2005. Buku Ajar Fundamental Keperawatan ; Konsep, Proses, dan Praktik. Vol 1. Ed 4. Jakarta : ECG

Prihatiningsih, D. (2012). Hubungan komunikasi terapeutik dengan tingkat cemas pasien di ruang Melati RSUD Kebumen. STIKES Muhammadiyah Gombong.

Rasmun. 2004. Stress, Koping dan Adaptasi Teori dan Pohon Masalah Keperawatan. Jakarta : CV Sagung Seto 
Marlen Febiyana Patty, Dewi Kartika Sari \& Yafet Pradikatama, Hubungan Komunikasi Terapeutik Perawat Terhadap Tingkat Stres Pasien di Ruang Neurologi Rumah Sakit Umum Daerah dr M.Haulussy Ambon

Rosalind, Elliot., Lucie, Wright. 1999. Verbal communication : what do critical care nurses say to their unconscious or sedated patients? Journal of Advanced Nursing .Vol 29

Rusmini. 2006. Hubungan komunikasi terapeutik dengan stres pasien di RSU Doris Sylvanus Palangkaraya

Smet, B. 1994. Psikologi Kesehatan. Jakarta : Gramedia Widiasarana Indonesia
Suryani. 2006. Komunikasi Terapeutik Teori dan Praktik. Jakarta : EGC

Sunaryo. 2002. Psikologi Untuk Keperawatan. Jakarta : ECG

Shika, A., Smita. J. 2013. Anasakti : Stress and Coping in Old Age. Vol 27. Indian Journal of Gerontology

Sugiyono. 2008. Metode Penelitian Kuantitatif Kualitatif dan $R \& D$. Bandung : Alfabeta 